\title{
ESTIMATION OF HERITABILITY COEFFICIENTS OF NUMBER OF BORN ALIVE PIGLETS IN THE FIRST THREE FARROWINGS SWEDISH LANDRACE SOWS
}

\author{
R. Savić1, M. Petrović ${ }^{2}$ Č. Radović ${ }^{3}$ \\ ${ }^{1}$ A.D. Doža Djerdj, 24300, Bačka Topola, Republic of Serbia \\ ${ }^{2}$ Faculty of Agriculture, 11080, Belgrade-Zemun, Republic of Serbia \\ ${ }^{3}$ Institute for Animal Husbandry, 11080, Belgrade-Zemun, Republic of Serbia \\ Corresponding author: arsavic@gmail.com \\ Original scientific paper
}

\begin{abstract}
The main objective of this study was to evaluate phenotypic and genetic variation of the number of piglets born alive (NBA) Swedish Landrace sows (SL) in three consecutive parities under the influence of sires, year and season of mating. The study included: 618 litters in the first, 470 in the second and 403 litter in the third farrowing. Testing the homogeneity of variance was performed with Levene's test. The data were analyzed using analysis of variance (Statistica Ver. 6.0., 2003). Heritability coefficients were evaluated by intra-class correlation. Swedish Landrace sires have influenced on the variability of the NBA's daughter in the first and second farrowing $(\mathrm{p}<0.05)$, but not in the third farrowing. Year and season of mating was not influenced on the variability of the NBA $(p>0.05)$. The estimated heritability coefficients for the NBA were the highest in the second (0.123), then the first (0.092) and lowest in the third farrowing (0.030).
\end{abstract}

Key words: sows, litter size, heritability, sires, year, season

\section{Introduction}

Reproductive traits such as litter size, litter weight at birth and survival rates of piglets to weaning, are the most important economic trait in swine production (Yen et al., 1987). The objective of modern pig breeding is to exhaust the genetic potential in reproduction performance of sows regarding to litter size and number of weaned piglets per litter (Wähner and Brüssow, 2009). Litter size is one of the most important reproductive traits. It is a low heritable trait and the influence of environmental factors on its expression is significantly expressed, because it is necessary 8 to 10 generations of selection to increase litter size by one piglet (Kosovac et al., 1996).

Knowledge of genetic parameters of reproductive traits is an essential requirement in estimating the breeding value, selection, implementation and select 
the best method of breeding, because only in this way can the right to genetic improvement of the herd. Heritability in the narrow sense determines the method and evaluate the effect of selection, because of additive gene effect has more influence on the expression of quantitative traits (Kosovac et al., 1996). A large number of tests of litter size in different populations of pigs showing a low coefficient of heritability of $10 \%$ and a relatively high variance of $25 \%$ (Petrović et al., 1997).

There are differences in the estimated values of heritability coefficient for the same trait depending on the method used (Petrović et al., 1997). Roehe and Kennedy (1995) are using multiple-trait animal model and determine low heritability coefficient values that were increased from first to fourth parities (0.086, 0.096, 0.116 and 0.141) Landrace sows. According to the results Tholen et al. (1995), heritability coefficients for number of live born piglets in two herds, in the first three parities were of 0.09 to 0.16 .

Data analysis sought to determine how sires, year and season of mating influence the phenotypic and genetic variability of traits of litter size (number of piglets born alive). The aim was to estimate heritability coefficient for the number of live born piglets in three consecutive parities.

\section{Materials and Methods}

The study uses data on fertility of sows of Swedish Landrace (SL), since 2000. by 2008. year from a commercial type farms. After calculating the distribution of number of daughter by father and setting the criteria of "a minimum of 10 daughters by sires", made the formation of subsamples that include the daughters of the ten selected sires with balanced distribution of litters by farrowing ordinal numbers. The number of analyzed litters at farrowing is: 618 in the first, 470 in the second and 403 litters in the third farrowing. The trait of number of born alive piglets (NBA) in this study involved a number of live born piglets, increased body weight of 800 grams.

Data processing was performed using the statistical package Statistica Ver. 6.0. (StatSoft Inc., 2003). Were applied a standard statistical methods. Depending of the observed factors in the analysis of variance was used mathematical and statistical model:

$$
\mathrm{Y}_{i j k l}=\mu+\mathrm{N}_{i}+\mathrm{G}_{j}+\mathrm{S}_{k}+\mathrm{E}_{i j k l},
$$

where: $\mathrm{Y}_{\mathrm{ijkl}}$ - number of piglets born alive, $\mu$ - average value, $\mathrm{Ni}$ - random effect of sires, $\mathrm{Gj}_{\mathrm{j}}$ - fixed effect of the year of mating, $\mathrm{Sk}$ - fixed effect of the season of mating and Eijkl- random error.

Testing the homogeneity of variance, or whether the data meet the requirements for the application of the methodology was performed with Levene's 
test (Petrie and Watson, 2006). Testing (comparison) the average values obtained by descriptive statistical analysis was done by t-test.

Estimates of heritability coefficients was performed by intra-class correlation of paternal half-sisters in the first, second and third farrowing sows. The analysis included nine consecutive years and all four seasons of mating. Standard error of heritability was calculated using the form Končar and Simić (1978).

\section{Results and Discussion}

Descriptive statistical parameters of number of born alive piglets in sows of Swedish Landrace by farrowing are shown in Table 1.

Number of live born piglets is low, but increases from first to third parities (8.44 to 9.97). Relative indicator of variability $(\mathrm{CV}=25.94$ to 29.66$)$ points to the relative homogeneity of the trait of the number of live born piglets in the first three parities.

Table 1. Descriptive statistical parameters of number of born alive piglets (NBA) of Swedish Landrace sows in the first three parities

\begin{tabular}{|c|c|c|c|}
\hline \multirow{2}{*}{ Parameter } & \multicolumn{3}{|c|}{ Parity of farrowing } \\
\cline { 2 - 4 } & 1 & 2 & 3 \\
\hline $\mathrm{n}$ & 618 & 470 & 403 \\
\hline $\bar{x}$ & $8.44^{\mathrm{A}}$ & $9.44^{\mathrm{B}, \mathrm{a}}$ & $9.97^{\mathrm{B}, \mathrm{b}}$ \\
\hline $\mathrm{S} \bar{x}$ & 0.10 & 0.12 & 0.13 \\
\hline $\mathrm{CV}$ & 29.66 & 27.48 & 25.94 \\
\hline $\mathrm{SD}$ & 2.50 & 2.59 & 2.58 \\
\hline
\end{tabular}

Differences between mean values marked with different letters are statistically significant: $\mathrm{AB}=\mathrm{p}<0.001, \mathrm{ab}=\mathrm{p}<0.01$

Comparing the average values NBA between farrowing exhibited a statistically highly significant difference $(\mathrm{p}<0,001)$ between the litter size of primiparous sows and litter sows in the second and third farrowing, while the difference in litter size between the second and third parities is significant $(\mathrm{p}<0,01)$.

Levene's test of homogeneity of variance by the factors of the model (Table 2) indicates that the Swedish Landrace sows in the third farrowing there was a statistically lower significant difference $(p<0,05)$ between the variances by year of mating. Value variance properties of the number of live born piglets for year of mating in the third farrowing from 2.93 (year 9) to 16.25 (year 1). In all other cases, in all three parities, the variance in the observed factors (sires, year and season) are homogeneous, and among them there was no statistically significant difference. 
Homogeneity of variance determined by the factors of the model justifies the use of methods of analysis of variance to access the observed impact on litter size.

Analysis of variance (Table 3) shows that the Swedish Landrace sires influenced on the variation of the number of live born piglets in the first and second, but not in the third farrowing daughters. Year and season of mating within individual farrowing did not significantly affect on the variation of the NBA ( $>>0.05)$. The results are consistent with research Radojković et al. (2007) that found that the boars influenced on the variation of the number of live born piglets in first litter daughter, and year and season were not influenced significantly on the variation of these traits.

Table 2. Results of Levene's variance homogeneity test of number of born alive piglets per factors involved in the model observed by the ordinal number of farrowing

\begin{tabular}{|c|c|c|c|c|c|}
\hline $\begin{array}{c}\text { Order of } \\
\text { farrowing }\end{array}$ & Factor & MSef & MSg & F & $\mathrm{p}$ \\
\hline \multirow{3}{*}{1} & Sire & 3.222736 & 2.180420 & 1.478034 & 0.152285 \\
\cline { 2 - 6 } & Year & 4.063620 & 2.246363 & 1.808977 & 0.072552 \\
\cline { 2 - 6 } & Season & 2.476417 & 2.216010 & 1.117512 & 0.341273 \\
\hline \multirow{3}{*}{2} & Sire & 2.946778 & 2.510424 & 1.173817 & 0.309749 \\
\cline { 2 - 6 } & Year & 2.725185 & 2.500661 & 1.089786 & 0.368862 \\
\cline { 2 - 6 } & Season & 0.560710 & 2.486074 & 0.225540 & 0.878634 \\
\hline \multirow{3}{*}{3} & Sire & 2.698323 & 2.393963 & 1.127136 & 0.342107 \\
\cline { 2 - 6 } & Year & 4.953463 & 2.412145 & 2.053551 & 0.039377 \\
\cline { 2 - 6 } & Season & 5.923849 & 2.492488 & 2.376681 & 0.069517 \\
\hline
\end{tabular}

MSef- average squared effects; MSg- average square error; F- value; p- significance

The estimated heritability coefficients were low, but the calculated values were different at farrowing (Table 3). Heritability coefficients for number of born alive piglets in the first three parities were: $0.092,0.123$ and 0.030 .

Variance between fathers was highest in the second farrowing $\left(\mathrm{O}^{2}{ }_{\mathrm{BS}}=0.206\right)$, and lowest in the third $\left(\mathrm{O}^{2}{ }_{\mathrm{BS}}=0.050\right)$ when the variance within the sires, so between the daughters was the largest $\left(\sigma^{2}{ }_{\mathrm{wS}}=6.679\right)$. In the third farrowing reduced the average square between sires $\left(\mathrm{MS}_{\mathrm{BS}}=8.559\right)$, increased the average of squares within the sires $\left(\mathrm{MS}_{\mathrm{ws}}=6.679\right)$ and reduced the average number of daughters $(\mathrm{k}=37.692)$ compared with the second farrowing. This resulted on the reduction of variance between sires $\left(\sigma^{2}{ }_{B S}=0.050\right)$. Variations of the number of born alive piglets in the third farrowing increased between the daughters 
of the same sire, so the standard deviation (SD) was from 1.98 (sire 13449) to 4.01 piglets (sire 757).

In research conducted a calculated value of the coefficient of heritability for number of born alive piglets in the first farrowing sows SL was low but slightly higher $\left(\mathrm{h}^{2}=0.092 \pm 0.054\right)$ with less error than are found Radojković et al. (2005, $h^{2}=0.083 \pm 0.058$ ). The results are consistent with research Petrović et al. (1998) who found that heritability coefficient was $0.092 \pm 0.021$. The obtained values of heritability for litter size in Landrace were lower in the first and second, and higher in the third farrowing than they found Irgang et al. (1994). Compared with the results of the coefficient of heritability for NBA Landrace sows (Kim, 2001), the estimated value of heritability in this study are higher in the first and second, and lower in the third farrowing. The values of the coefficient of heritability for number of born alive piglets in this study are lower than the results of Suarez et al. (2004) who determine, in the first three Landrace sows farrowing, the coefficients of heritability of 0.16 to 0.27 .

Table 3. Results of the analysis of variance and the estimated coefficients of heritability of NBA of sows purebred SL in the first, second and third farrowing

\begin{tabular}{|c|c|c|c|c|c|c|c|c|}
\hline $\begin{array}{l}\mathrm{R} \\
\mathrm{B} \\
\mathrm{L}\end{array}$ & $\begin{array}{l}\text { Source of } \\
\text { variation }\end{array}$ & $\mathrm{df}$ & SS & MS & F & $\sigma^{2}$ & $\mathrm{k}$ & $\mathrm{h}^{2} \pm \mathrm{Sh}^{2}$ \\
\hline \multirow{5}{*}{1} & Between sires & 9 & 130.578 & 14.509 & $2.345^{*}$ & 0.146 & \multirow{5}{*}{57.019} & \multirow{5}{*}{$0.092 \pm 0.054$} \\
\hline & Year & 8 & 38.686 & 4.836 & $0.782^{\text {ns }}$ & - & & \\
\hline & Season & 3 & 1.701 & 0.567 & $0.092^{\mathrm{ns}}$ & - & & \\
\hline & Within sires & 597 & 3693.074 & 6.186 & - & 6.186 & & \\
\hline & Sum & 617 & 3864.039 & - & - & - & & \\
\hline \multirow{5}{*}{2} & Between sires & 9 & 139.446 & 15.494 & $2.378^{*}$ & 0.206 & \multirow{5}{*}{43.663} & \multirow{5}{*}{$0.123 \pm 0.070$} \\
\hline & Year & 8 & 67.974 & 8.497 & $1.304^{\mathrm{ns}}$ & - & & \\
\hline & Season & 3 & 24.654 & 8.218 & $1.261^{\mathrm{ns}}$ & - & & \\
\hline & Within sires & 449 & 2925.875 & 6.516 & - & 6.516 & & \\
\hline & Sum & 469 & 3157.949 & - & - & - & & \\
\hline \multirow{5}{*}{3} & Between sires & 9 & 77.034 & 8.559 & $1.281^{\mathrm{ns}}$ & 0.050 & \multirow{5}{*}{37.692} & \multirow{5}{*}{$0.030 \pm 0.045$} \\
\hline & Year & 8 & 13.635 & 1.704 & $0.255^{\mathrm{ns}}$ & - & & \\
\hline & Season & 3 & 43.356 & 14.452 & $2.164^{\mathrm{ns}}$ & - & & \\
\hline & Within sires & 382 & 2551.488 & 6.679 & - & 6.679 & & \\
\hline & Sum & 402 & 2685.513 & - & - & - & & \\
\hline
\end{tabular}


RBL- order of farrowing; df- number of degrees of freedom; SS- sum of squares; MS- average square; F- value; $\sigma^{2}$ - variance; $\mathrm{k}$ - average number of daughters; $\mathrm{h}^{2}$ - heritability coefficient; $\mathrm{Sh}^{2}-$ standard error of heritability

Comparison of results of heritability coefficients between farrowing, shows that the heritability of number of born alive piglets in the second farrowing is largest. Explanation of increased heritability in the second farrowing may be a weaker selection criteria applied to the primiparous sows. In fact, after the first farrowing sows are not yet completed growth and are not fully expressed their reproductive potential (Radojković et al., 2005). As a consequence, an increase of genetic variability in the second farrowing. The estimated value of heritability of born alive piglets in the third farrowing is lower than in the second farrowing. The reason may be tightening criteria for selection of sows after second farrowing, causing a reduction in additive genetic variation. The conclusions are supported by the research Radojković et al. (2005). Conclusions about the reasons for decrease of heritability in the third farrowing similar to the results Irgang et al. (1994). According to some researchers, the coefficient of heritability of litter size (NBA) increased from first to third parities (cited Kosovac et al., 1996), which is in contrast with the results of this study. Number of born alive piglets in this study involved a number of live born piglets greater body mass of 800 grams. It was due to a reduced variability in these traits in the studied herd. With increasing age of sows and ordinal number of farrowing (from first to third) increased variance within the sires and increased at varying NBA between daughters of the same father, which influenced on the coefficient of heritability.

\section{Conclusion}

In this paper study the evaluation of phenotypic and genetic variation of the number of piglets born alive (NBA) Swedish Landrace sows (SL) in three consecutive parities under the influence of sires, year and season of mating. Based on the results of this study can be seen that the average of number of piglets born alive (NBA) is low, but increased from first to third parities (8.44-9.97).

Results of analysis of variance showed a statistically significant effect of sires Swedish Landrace on the variability and average expression of the NBA daughter in the first and second farrowing $(\mathrm{p}<0.05)$. Year and season of mating did not affect on the variability of the NBA ( $>>0.05)$.

Heritability coefficients for number of born alive piglets in the first three parities were: $0.092,0.123$ and 0.030 . 


\title{
Procena koeficijenta heritabiliteta za broj živorođene prasadi u prva tri prašenja krmača švedskog landrasa
}

\author{
R. Savić, M. Petrović, Č. Radović
}

\section{Rezime}

Osnovni cilj rada bio je da se oceni fenotipska i genetska varijabilnost broja živorođene prasadi (NBA) krmača švedskog landrasa (SL) u tri uzastopna prašenja pod uticajem očeva, godine i sezone pripusta. Istraživanjem je bilo obuhvaćeno: 618 legala u prvom, 470 u drugom i 403 legla u trećem prašenju. Testiranje homogenosti varijanse izvršeno je testom Levene-a. Dobijeni podaci su obrađeni metodom analize varijanse (Statistica Ver. 6.0., 2003). Koeficijenti heritabiliteta su ocenjeni metodom intra-klasne korelacije. Očevi švedskog landrasa uticali su na varijabilnost NBA kćeri u prvom i drugom prašenju $(p<0.05)$, ali ne $i$ u trećem prašenju. Godina i sezona pripusta nisu uticale na varijabilnost NBA ( $>0.05)$. Procenjeni koeficijenti heritabiliteta za NBA su bili najviši u drugom (0.123), zatim u prvom (0.092) i najniži u trećem prašenju (0.030).

\section{References}

IRGANG R., FAVERO J. A., KENNEDY B. W. (1994): Genetic parameters for litter size of different parities in Duroc, Landrace, and Large White sows. Journal of Animal Science, 72, 2237-2246.

KIM HYUNG-JOO (2001): Genetic Parameters for productive and reproductive traits of sows in multiplier farms. Institute of Animal Breeding and Genetics Georg-August-University of Göttingen, Doctoral Dissertation.

KONČAR L., SIMIĆ M. (1978): Oplemenjivanje domaćih životinja. Univerzitet u Novom Sadu, Poljoprivredni fakultet, 1-417.

KOSOVAC O., PETROVIĆ M., ŽIVKOVIĆ B., GLUHOVIĆ M., FABJAN M. (1996): Genetski parametri osobina plodnosti kod svinja. Biotehnologija u stočarstvu, 12, 3-4, 57-66.

PETRIE AVIVA, WATSON P. F. (2006): Statistics for veterinary and animal science. Blackwell Publishing, second edition, 1-299.

PETROVIĆ M., TEODOROVIĆ M., KOSOVAC O., RADOJKOVIĆ D. (1997): Ocena i upotreba genetskih parametara u poboljšanju reproduktivnih osobina svinja (pregled). Simpozijum: „Naučna dostignuća u stočarstvu '97.“, Subotica, 21.-25. april. 
PETROVIĆ M., TEODOROVIĆ M., RADOJKOVIĆ D., KOSOVAC O. (1998): Determinacija faktora koji utiču na variranje reproduktivnih osobina krmača. Savremena poljoprivreda, 47, 5-6, 121-126.

RADOJKOVIĆ D., PETROVIĆ M., MIJATOVIĆ M. (2005): Estimation of genetic variability of fertility traits of pigs. Biotechnology in Animal Husbandry, 21, 3-4, 93-97.

RADOJKOVIĆ D., PETROVIĆ M.., MIJATOVIĆ M., RADOVIĆ Č. (2007): Phenotypic variability of fertility traits of pure breed sows in first three farrowings. Biotechnology in Animal Husbandry, 23, 3-4, 41-50.

ROEHE R., KENNEDY B. W. (1995): Estimation of genetic parameters for litter size in Canadian Yorkshire and Landrace swine with each parity of farrowing treated as a different trait. Journal of Animal Science, 73, 2959-2970.

StatSoft, Inc. (2003): STATISTICA (data analysis software system), version 6 . www.statsoft.com.

SUAREZ M., HERMESCH SUSANNE, BRAUN J., GRASER H.-U. (2004): Genetic Parameters of reproductive traits recorded at different parities in Landrace and Large White sows. AGBU Pig Genetics Workshop.

THOLEN E., BUNTER K., HERMESCH S., GRASER H. U. (1995): The Genetic Foundation of Fitness and Reproduction Traits in Australian Pig Populations (II.Relattionships between weaning to conception interval, farrowing interval, stayability and other common reproduction and production traits). AGBU Pig Genetics Workshop.

YEN H. F., ISLER G. A., HARVEY W. R., IRVIN K. M. (1987): Factors affecting reproductive performance in swine. Journal of Animal Science, 64, 1340-1348.

WÄHNER M., BRÜSSOW P. K. (2009): Biological potential of fecundity of sows. Biotechnology in Animal Husbandry, 25, 5-6, 523-533. 